of the stocks of fish, and, unless and until man devises the means of regularising the supply of nutrient salts in the surface waters, these natural fluctuations are inevitable and uncontrollable. Who can disperse the clouds below the sun, or modify the incidence of summer storms?

Science is not quite helpless even under these conditions, for, as the age of individual fishes can now be determined, the effects of good and bad years, when the data are adequate, can be traced to their causes, and can be followed in the actual stocks of fish through considerable cycles of years. It is thus becoming possible to predict from the age-composition of a stock of herring, haddock, etc., in a given year and its predecessors, what it is likely to be in the ensuing season. In this way Mr. Hodgson, of the Lowestoft Laboratory of the Ministry of Fisheries, last September made a remarkably close forecast of the autumn herring fishery, and leaders of the industry have already expressed their appreciation of the commercial value of such forecasts. To be forewarned is to be forearmed, and may mean the annual saving of many thousands of pounds in an industry which requires large anticipatory provision of apparatus, stores, and personnel.

From the point of view of farming the sea, the magnitude of modern fishery operations is a fact of cardinal importance, since the collective power of the fishing fleets is no longer negligible in comparison with the blind forces of Nature. It was formerly thought that this power was merely destructive; but the problem is one of dynamics, not statics, and the destruction entailed by fishing is now known to be balanced by an increased rate of production. It is the quality rather than the quantity of fish that is changed by it. Like the destructiveness of Nature, that of the fishing fleets operates as a selective agency, and is creative of new conditions, some of which are manifestly beneficial. It is possible that the hosts of herring have been actually increased in consequence of the elimination by trawlers of the large haddocks which feed upon their spawn. It is certain that the removal of old plaice favours the survival and growth of the young, the precise nature of the result depending also on a further factor, the greater or less amount of local reproduction. In the Cattegat and Baltic, where reproduction is limited, the effect of intense fishing is seen in a great increase in the growth-rate, coupled with a reduction in numbers, thus raising the average size. A race of small, slow-growing and worthless fish has been converted into one of large, quick-growing and valuable fish, but it is feared that the rate of reproduction is insufficient to meet the steady reduction in numbers.

On the other hand, in the North Sea, with a high rate of reproduction, the effect of intense trawling is to increase the survival of the young and their emigration offshore, so that the increase of their growth-rate is checked at a certain level by additional numbers. The increase of small fish in the catches, formerly regarded as evidence of 'over-fishing', is really the greatest safeguard against it, for it means that, however intense the fishing, the gaps are immediately filled from inexhaustible reserves.

If these arguments are soundly based - and the recent experience of post War changes overwhelmingly supports them-the North Sea problem is reduced to the question of how to increase the average size of the fish without reducing the intensity of fishing. So far as the plaice is concerned, the answer is already available.

One of the first results of scientific investigation of the North Sea was to show that the Dogger Bank, with an area as large as Wales, lies outside the track of normal plaice migration, and yet possesses enormous reserves of the favourite food of this fish. The one unimpeachable method of raising the size of plaice in the North Sea is to utilise this great reserve for the purpose, and to transplant every year some millions of the small overerowded and slow-growing fish from the coastal banks to this great feeding ground, on which it has been shown repeatedly that the plaice transplanted grow three, four, and even six times as rapidly as on their natives shores.

Science is useless without enterprise. Great Britain looks to the traditional enterprise of the great Humber fishing ports to take up this matter as a commercial proposition. Let Grimsby and Hull take the first step towards cultivating the 'Great Fish Farm ' which lies at their very door.

\title{
Opening of the Forest Research Institute at Dehra Dun, India.
}

THE February issue of the Indian Forester is a commemoration number devoted to a detailed account of the opening of the new buildings of the Forest Research Institute at Dehra Dun, India. A brief announcement of this event has already appeared in NATURE (Nov. 16 and 30,1929 ).

The new main building was opened by the Viceroy on Nov. 7, 1929. Perhaps the most important part of Lord Irwin's speech was his allusion to the work of the expert committee appointed under the presidency of Sir Chunilal Mehta "to advise them about the functions and policy of the Institute and the future of its activities". The report of this Committee was presented and made public last sumrer and the Viceroy explained some of its recommendations as follows : "In the report they made a number of most helpful suggestions and laid down, with admirable judgment and lucidity, the line of policy which should be pursued in the future. . . I I am happy to be able to say that the bulk of their recommendations have already been taken up in consultation with Mr. Rodger and that we hope to give effect, in due course, to very many of them. We intend within the limits of our financial liability to give this Institute, now so finely housed and located, the scientific staff which it requires, and to omit or neglect no measure which we think will make for its continued success and greater usefulness.

"The Institute, and the various allied activities of which it is the centre, must, as I see it, aim at the discharge of a double purpose. On the most effective utilisation of Indian woods, I have already spoken, but it is not less our desire to train Indian personnel in all the technical branches of forestry research work. The governing consideration must remain that of efficiency.'

Mr. (now Sir Alexander) Rodger, Inspector-General of Forests and president of the Forest Research Institute, in his address of welcome to the Viceroy and Lady Irwin, pointed out that Dehra Dun has been the centre for forest work since 1878, when a forest college was founded for training rangers and foresters. Forest research work has been in close touch with education since 1906, when the Research Institute was inaugurated, though, as a matter of fact, in two branches, chemistry and forest zoology, the ranger class had the benefit of lecture courses from research officers several years antecedent to 1906 . Sir Alexander alluded to the enormous expansion in personnel since 1906. In the latter year there were five gazetted officers and one non-gazetted officer appointed to the charge of the six branches into which

No. 3156 , VoL. 125] 
f orest research was subdivided. Each officer had a small clerical staff allotted. In 1929 the staff had expanded until the Institute now employs thirty-five gazetted officers, two hundred and twenty assistants and subordinates, and three hundred and fifty men on daily labour. It is this great development which necessitated the construction of the great buildings opened by the Viceroy on Nov. 7.

In 1906 no special accommodation was available. The first large building was erected at Chand Bagh and opened in 1914. It was confidently expected that this building would suffice for all possible requirements of the Institute for a number of years to come. The development of the forest resources of India made such strides during the War that the Industrial Commission pointed out in 1918 the necessity of expanding the Institute to meet the rapidly increasing demands of the country. The Commissioners advocated the increase of the number of research officers and stated that the equipment provided was entirely inadequate. These recommendations were accepted by both the Government of India and the Secretary of State, and, in spite of later suggestions for cutting down the scale of the new proposals, they survived the ordeal. The workshops of the economic branch were completed and in working order in 1924 and the main building was occupied during the years 1926 and 1928 . The total cost of the new establishments is close upon one million pounds.

The three most handsome rooms in the Forest Research Institute are the new library, in Andamans padauk, the large hall, all Burma teak, and the entrance hall, shisham and rosewood. Another room which is very effective is the office of the forest economist, which is panelled in poon (Calophyllum) from Madras. The other rooms are not so decorative, but, as Burma teak of good quality has been used throughout; they are mostly handsome as well as useful. A special feature has been made of the windows, with good lighting for laboratory work. There are six museums, with floor space of 26,000 square feet, and the ordinary rooms designed for laboratories and offices cover about 63,000 square feet.

In the grounds, besides the workshops of the economic branch are offices for the different branches and numerous residences of all kinds for the staff.

As at first arranged, the buildings at Chand Bagh were to be utilised as the training centre for the Indian probationers for the Indian Forest Service, whose two years' course of training in forestry is now being given at Dehra Dun. It was perhaps too much to hope to keep Chand Bagh in the Department, even though so much forest history has grown up around it. The beautiful building is to be given up and it is to be utilised in the future for medical research work; while part of the new Institute building will be devoted to the educational requirements of the Indian Forest Service probationers.

The chief value of this commemoration number of the Indian Forester, for the future, will not be confined to the account of the opening proceedings of the new buildings. For the latter is followed by a valuable detailed account of the past history and development of the various branches of the Institute from the date of its inauguration in 1906.

\section{Archæology from the Air in Central America.}

$\mathrm{T}^{\mathrm{H}}$ HE definitive account of the recent archæological reconnaissance by air in Central Arnerica, to which reference has already been made in our columns (see Nature, Dec. 28, 1929, p. 995), appears in the April number of the Geographical Review (New York). The authors are Mr. Oliver J. Ricketson and Dr. A. V. Kidder, who acted as observers. The text is illustrated by a number of photographs taken by $\mathrm{Mr}$. Ricketson and Mrs. Lindbergh. As previously noted, the leader of the expedition was Col. Lindbergh, who originally suggested the idea of the reconnaissance to the Smithsonian and Carnegie Institutions.

To enable their readers to appreciate the significance of the observations on the four flights which were made, the authors recapitulate the main divisions and distribution of the remains of ancient Maya civilisation. The oldest remains are found at Peten in Guatemala, whence the city-building activities of the Maya were carried to what is now British Honduras and Yucatan. The classic period of the Old Empire, lasting from about the beginning of the Christian era to 610 , was followed by a migration to lands of which northern Yucatan became the most important. There a renaissance took place in the eleventh and twelfth centuries which is marked by the magnificent buildings of Uxmal and Chichen Itzá. Later, the Mexicanisation of Maya art and religion, after the calling in of the Nahua tribes, led to a time of vigorous growth and building activity followed by a hundred years of decadence which ended with the Spanish conquest.

A great deal of the country which was thus occupied is still unexplored. Short of cutting a way through the almost impenetrable bush, the only means of access are the paths of the chichle gatherers (chichle is the sap which forms the basis of chewing gum): Although these paths are gradually opening up the country, they still do not join, and the country lying between is unknown. As travel by bush path gives no opportunity for topographical observation, the general aspect, geographical features, and contour of the Maya country are not known. As became apparent from the observations made on these flights, the existing maps are untrustworthy as regards the situation of natural features, existing settlements, towns, and ruins. Several unmapped natural features were recorded for the first time.

The flights began on Oct. 6, 1929, and a flight was made on each subsequent day up to and including Oct. 10. On the last day, however, comparatively little time was spent in archæological observation, as the party flew to Havana and Miami. The flights were usually at an altitude of 500 feet, as this was found the best for observation, and the average speed was 85 miles per hour. The difficulties of observation owing to the density of the vegetation will be appreciated from the fact that on several occasions the aeroplane circled and recrossed known sites without the observers being able to 'spot' the ruins. It was desired to follow the great causeway which runs for at least fifteen miles from Coba, but although the exact spot at which it leaves the city was known, it could not be found.

The flight on Oct. 6 was from Belize to Merida, a

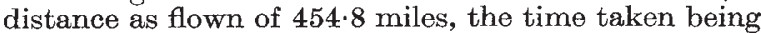
$5 \mathrm{hr} .21 \mathrm{~min}$. Owing to the inexperience of the observers, observation on this flight was found diff. cult; but as time went on rapidity and accuracy were found to come with experience. After spending the night at Merida, the party returned to Belize on Oct. 7 by a slightly shorter route, ending with a flight along the coast, the distance covered being 373 miles in $4 \mathrm{hr} .23 \mathrm{~min}$. On this flight, Chichen Itzá and Yaxuna were visited and a landing made at Lake Payegua. On Oct. 8 a flight was made to Flores, the return being by the southward of the Cockscomb range. On this journey Yaxha, where a landing was

No. 3156, VoL. 125] 